\title{
Resorption Efficiency of Four Cations in Different Tree Species in a Subtropical Common Garden
}

\author{
Yaoyi Zhang, Xiangyin Ni, Jing Yang, Siyi Tan, Shu Liao, Dingyi Wang, Kai Yue and Fuzhong Wu
}

Key Laboratory for Humid Subtropical Eco-Geographical Processes of the Ministry of Education, School of Geographical Sciences, Fujian Normal University, Fuzhou, 350007, China

*Corresponding Author: Fuzhong Wu. Email: wufzchina@fjnu.edu.cn

Received: 08 February 2021 Accepted: 22 April 2021

\begin{abstract}
High rainfall in subtropical regions can leach cation elements from ecosystems, which may limit plant growth. Plants often develop efficient resorption patterns to recycle elements, but there is relatively little available information on this topic. In February 2012, a common garden was established in a subtropical forest by planting dominant trees from the area. Green and senescent leaves were sampled from 11 tree species. The concentrations of potassium $(\mathrm{K})$, calcium $(\mathrm{Ca})$, sodium $(\mathrm{Na})$ and magnesium $(\mathrm{Mg})$ were determined, and the resorption efficiencies were calculated. The results showed significant $\mathrm{K}, \mathrm{Na}$ and $\mathrm{Mg}$ resorption in most of the investigated tree species, while Ca mainly displayed accumulation. Evergreen coniferous and evergreen broad-leaved trees (such as Cunninghamia lanceolata, Pinus massoniana, Cinnamomum camphora, and Michelia macclurei) exhibited relatively higher resorption efficiencies of $\mathrm{K}(39.0 \%-87.5 \%)$ and $\mathrm{Na}(18.3 \%-50.2 \%)$ than deciduous broad-leaved trees. Higher $\mathrm{Mg}$ resorption efficiencies ( $>50 \%)$ were detected in Liriodendron chinense, C. lanceolata and P. massoniana than in other trees. Overall, evergreen coniferous and evergreen broad-leaved trees could show higher cation resorption than deciduous broad-leaved trees. $\mathrm{K}$ and $\mathrm{Mg}$ resorption efficiencies and $\mathrm{Ca}$ accumulation decrease with increasing nutrient concentrations in green leaves. Our results emphasize that nutrient resorption patterns largely depend on elements and plant functions, which provides new insights into the nutrient use strategies of subtropical plants and a reference for the selection of suitable tree species in this region.
\end{abstract}

\section{KEYWORDS}

Nutrient use strategy; cations; common-garden trees; nutrient resorption; subtropical forest

\section{Introduction}

Cation elements, such as potassium $(\mathrm{K})$, calcium $(\mathrm{Ca})$, sodium $(\mathrm{Na})$ and magnesium $(\mathrm{Mg})$, are nutrients that play essential roles in the growth of plants [1,2]. Like other nutrients, these elements can be retransferred to new tissues during senescence [3]; therefore, resorption is considered to be one of the most crucial nutrient conservation strategies, helping to maintain the balance of nutrients in plant tissues $[4,5]$ and reducing the dependence of plants on soil nutrient supplies $[6,7]$. Therefore, it is essential to investigate nutrient resorption to better understand the nutrient use strategies of different tree species [3]. Generally, nutrient resorption can be quantified by resorption efficiency and resorption proficiency. Resorption efficiency is defined as the percentage of the reduction in nutrient concentrations between green leaves and senescent 
leaves, and this measurement is most suitable for quantifying the relative degree to which plants can provide nutrients to leaves. To more objectively and definitively estimate the degree to which the trees reused nutrients, resorption proficiency is defined as the nutrient concentration in senescent leaves [8].

Resorption patterns may differ among elements since they have different biochemical and physiological functions $[9,10]$. For example, $\mathrm{K}$ is associated with the metabolism of amino acids, proteins, enzymes and nucleic acids; $\mathrm{Mg}$ is component of chlorophyll and is critical for enzyme activities; and $\mathrm{Ca}$ and $\mathrm{Na}$ can be considered structural elements. Na can be substituted $\mathrm{K}$ in a certain extent. $\mathrm{Ca}$ is an important component of the cell wall. A study providing the first global estimate of multiple mineral nutrient resorption efficiencies showed that $\mathrm{K}$ exhibited the highest resorption efficiency. $\mathrm{Ca}, \mathrm{Na}$ and $\mathrm{Mg}$ can also be resorbed, although they show lower mobility [3]. Other studies have shown that $\mathrm{Ca}$ accumulates in senescent leaves $[11,12]$. In addition, a recent study suggested that due to the greater demand of plants for nucleic acid-protein elements, their resorption is increased over that of other elements, while some nutrients, such as enzymatic elements and structural elements, may be less favored in these pathways and cannot be resorbed $[10,11]$. Thus, the available findings regarding the resorption of base cation elements are still inconsistent. Therefore, it is necessary to study the resorption of cations to further determine the resorption patterns of multiple nutrients.

Nutrient resorption has often been reported to vary among plant functional types $[12,13]$. Vergutz et al. observed that the resorption efficiencies of $\mathrm{K}$ and $\mathrm{Mg}$ in deciduous trees are higher than those in evergreen trees [3], but Diehl et al. [14] reported that K resorption is not clearly associated with functional types. Since resorption is particularly crucial in low-fertility soils, the relationship between resorption and nutrient availability has also been extensively investigated. Some studies have not found a clear relationship between them [6,15], while other results have indicated that resorption is highly dependent on the nutrient status of plants and soil $[10,16,17]$. These different results might be related to plant nutrient status across different plant functional types $[3,18]$. More importantly, most previous studies have not taken the homogeneity of site conditions into consideration $[19,20]$. Therefore, it is of great significance to study nutrient resorption of different tree species at the same site.

Subtropical forests are of great significance for the timber supply, water conservation and climate regulation [21,22]. However, natural forests have been lost and replaced by large areas of pure artificial forests with a relatively homogeneous structure. In recent years, to restore and further improve the ecological services of planted forests, the establishment of mixed forests has become an important component of the sustainable management of regional forests. Thus, choosing suitable tree species has currently become one of the key issues in this field. Moreover, cation elements in the soil of subtropical forests are at high risk of leaching losses under continuous washing by rainfall [23], thereby limiting plant growth. Therefore, the strategy of cation element resorption in plants could be more important in subtropical regions with rich rainfall than that in other regions. However, most of the research on resorption in subtropical regions conducted to date has focused on nitrogen $(\mathrm{N})$ and phosphorus $(\mathrm{P})$ [16,24,25], while the resorption patterns of cation nutrients such as $\mathrm{K}, \mathrm{Ca}$, $\mathrm{Na}$ and $\mathrm{Mg}$ have not been well studied.

We hypothesized that trees in a subtropical common garden would display efficient $\mathrm{K}, \mathrm{Ca}, \mathrm{Na}$, and $\mathrm{Mg}$ resorption but that the resorption efficiency could be regulated by the nutrient status among functional types. To test this hypothesis, a common garden experiment was conducted by planting 11 dominant subtropical tree species in 2012 under conditions involving the same homogeneous soil substrate, forest age and forest management history. After seven years, we checked the concentrations of $\mathrm{K}, \mathrm{Ca}, \mathrm{Na}$ and $\mathrm{Mg}$ in green leaves and senescent leaves, and compared the resorption efficiencies of the all species during leaf senescence. The results will enable us to further understand the resorption patterns of cation elements 
among different functional tree species and provide basic data for tree species selection in planting subtropical forests.

\section{Materials and Methods}

\subsection{Study Sites}

This study was conducted at Sanming Research Station of Forest Ecosystem and Global Change, Fujian Province, China $\left(26^{\circ} 19^{\prime} \mathrm{N}, 117^{\circ} 36^{\prime} \mathrm{E}\right)$. It is connected with the Wuyi Mountains and Daiyun Mountains in the northwest and southeast, respectively. This area has a subtropical monsoon climate, and the mean annual air temperature is $19.5^{\circ} \mathrm{C}$. The average annual precipitation is $1700 \mathrm{~mm}$, occurring primarily from March to August. Concentrated rainfall can greatly contribute to the loss of cation elements in the soils. The topography is characterized by hilly terrain, with altitudes ranging from 250 to $500 \mathrm{~m}$ above sea level. The largest evergreen broad-leaved forest in China is distributed in the region, which shows a rich plant community composition and obvious stratification. The arbor layer mainly includes Schima superba, P. massoniana and Castanopsis kawakamii, while the shrub-grass layer mainly includes Setaria plicata, Camellia japonica and Lonicera japonica.

\subsection{Experimental Design}

After cutting down and burning the vegetation, a common garden was established at a forest stand with the same homogeneous soil substrate, forest age and forest management history in February 2012. Before afforestation, the entire site was divided into 33 blocks, each with an area of approximately $0.1 \mathrm{hm}^{2}$. According to a random block design, the 33 blocks were divided into 11 treatments, with 3 replicates for each treatment (11 trees $\times 3$ replicates). Seedlings of each tree species were planted in each treatment. Eleven dominant tree species from the subtropical zone were selected from three functional types, and biennial seedlings were planted at a density of 0.12 trees per square meter. The planted evergreen coniferous trees included C. lanceolata and P. massoniana; the evergreen broad-leaved trees included Lindera communis, C. camphora, S. superba, Castanopsis carlesii, M. macclurei and Elaeocarpus decipiens; and the deciduous broad-leaved trees included Liquidambar formosana, Sapindus mukorossi and $L$. chinense. The soil surface organic carbon concentration was $16.88 \pm 1.07 \mathrm{mg} \cdot \mathrm{g}^{-1}$, the total $\mathrm{N}$ concentration was $1.30 \pm 0.034 \mathrm{mg} \cdot \mathrm{g}^{-1}$, the total $\mathrm{P}$ concentration was $0.28 \pm 0.017 \mathrm{mg} \cdot \mathrm{g}^{-1}$, the $\mathrm{K}$ concentration was $14.5 \pm 2.8 \mathrm{mg} \cdot \mathrm{g}^{-1}$, the $\mathrm{Ca}$ concentration was $0.66 \pm 0.47 \mathrm{mg} \cdot \mathrm{g}^{-1}$, the $\mathrm{Na}$ concentration was $1.40 \pm 1.06 \mathrm{mg} \cdot \mathrm{g}^{-1}$, the $\mathrm{Mg}$ concentration was $1.48 \pm 0.57 \mathrm{mg} \cdot \mathrm{g}^{-1}$, and the $\mathrm{pH}$ was $3.67 \pm$ 0.26 [26,27]. Samples were collected during the rapid growth period in August 2019. We selected 5 trees in each sampling plot and collected samples from the upper, middle and lower layers of each standard tree. We chose healthy green leaves that were fully expanded, free from pests and diseases, and facing the sun. During sampling, we collected 4 or 5 fully expanded leaves as "green leaf samples" [28]. At the same time, twelve to fifteen pieces of leaves with obvious senescent characteristics (mostly yellow and red) that were located close to green leaves on the sampled trees were collected as "senescent leaf samples" [12]. The collected healthy green leaves and senescent leaves were placed between two moist pieces of filter paper and then in a Ziplock bag, and the samples were stored in the dark in an ice bag (internal temperature $<4^{\circ} \mathrm{C}$ ) until being brought to the laboratory to be tested. At the same time, the diameter at breast height, tree height, canopy closure, and the coverage of understory vegetation and litter in each sampling plot were determined (Tab. 1). 
Table 1: Data of growth and field occupation of the 11 tree species studied

\begin{tabular}{|c|c|c|c|c|c|c|c|}
\hline Species & $\begin{array}{l}\text { Forest age } \\
\text { (years) }\end{array}$ & $\begin{array}{l}\text { Mean breast } \\
\text { diameter }(\mathrm{cm})\end{array}$ & $\begin{array}{l}\text { Mean Height } \\
\text { (m) }\end{array}$ & $\begin{array}{l}\text { Understory vegetation } \\
\text { Coverage (\%) }\end{array}$ & $\begin{array}{l}\text { Canopy Density } \\
(\%)\end{array}$ & $\begin{array}{l}\text { Litter Coverage } \\
(\%)\end{array}$ & $\begin{array}{l}\text { Specific leaf area } \\
\left(\mathrm{cm}^{2} \cdot \mathrm{g}^{-1}\right)\end{array}$ \\
\hline Cunninghamia lanceolata & 7 & 16.8 & 10.33 & 85 & 53 & 10 & 93.03 \\
\hline Pinus massoniana & 7 & 9.71 & 6.29 & 80 & 53 & 43 & 48.50 \\
\hline Lindera communis & 7 & 10.58 & 7.19 & 12 & 83 & 85 & 105.24 \\
\hline Cinnamomum camphora & 7 & 8.79 & 5.96 & 83 & 80 & 72 & 114.40 \\
\hline Schima superba & 7 & 8.78 & 6.44 & 23 & 67 & 83 & 114.59 \\
\hline Castanopsis carlesii & 7 & 11.82 & 7.2 & 60 & 47 & 47 & 99.80 \\
\hline Michelia macclurei & 7 & 8.4 & 6.13 & 13 & 83 & 88 & 93.70 \\
\hline Elaeocarpus decipiens & 7 & 12.63 & 6.8 & 73 & 65 & 8 & 117.84 \\
\hline Liquidambar formosana & 7 & 9.44 & 8.69 & 70 & 68 & 10 & 156.33 \\
\hline Sapindus mukorossi & 7 & 8.33 & 7.09 & 90 & 53 & 17 & 177.73 \\
\hline Liriodendron chinense & 7 & 8.08 & 6.78 & 77 & 37 & 10 & 254.24 \\
\hline
\end{tabular}

\subsection{Chemical Analysis and Calculations}

The single leaf area was scanned first by leaf area meter. The specific leaf area $\left(\mathrm{cm}^{2} \cdot \mathrm{g}^{-1}\right)=$ leaf area $\left(\mathrm{cm}^{2}\right) /$ leaf dry weight $(\mathrm{g})$ [29]. The leaf samples were then dried at $105^{\circ} \mathrm{C}$ for $15 \mathrm{~min}$ and dried at $75^{\circ} \mathrm{C}$ for $48 \mathrm{~h}$ to constant weight in an oven. Thereafter, they were weighed and were ground in a grinder with a $0.3 \mathrm{~mm}$ screen. After the digestion of powdered samples in concentrated $\mathrm{HNO}_{3}$, the samples were heated at $160^{\circ} \mathrm{C}$ for $5 \mathrm{~h}$. The concentrations of $\mathrm{K}, \mathrm{Ca}, \mathrm{Na}$ and $\mathrm{Mg}$ were determined using inductively coupled plasma spectroscopy (ICP-MS, IRIS Advantage 1000, Thermo Elemental, Waltham, MA, USA).

To eliminate the error caused by the loss of leaf mass during senescence, in the calculation of the element resorption efficiency (RE) at this leaf stage [30], the following formula was used [3,12]:

$\mathrm{RE}=\left(1-\frac{\mathrm{Nu}_{\mathrm{sen}}}{\mathrm{Nu}_{\mathrm{gr}}} \mathrm{MLCF}\right) \times 100$

where $\mathrm{Nu}_{\mathrm{gr}}$ and $\mathrm{Nu}_{\text {sen }}$ are the nutrient concentrations on a mass basis in green and senesced leaves $\left(\mathrm{g} \cdot \mathrm{kg}^{-1}\right)$, respectively; and MLCF is the mass loss correction factor used to compensate for the loss of leaf mass during senescence (the ratios of the dry mass of senescent leaves to the dry mass of green leaves were calculated) [31]. In the following analyses, all $\mathrm{Nu}_{\text {sen }}$ values were corrected to account for mass loss during senescence as $\mathrm{Nu}_{\text {sen }} *=\mathrm{Nu}_{\text {sen }}$ MLCF.

To determine the role of leaf nutrient status in determining the resorption efficiency, we used a power law regression according to Kobe et al. [32]:

$\mathrm{Nu}_{\mathrm{sen}}=\alpha \mathrm{Nu}_{\mathrm{gr}}^{\beta}$

where $\alpha$ and $\beta$ are regression parameters. $\beta>1$ indicates that the nutrient resorption efficiency decreases with increasing leaf nutrient status. In contrast, $\beta<1$ indicates that the nutrient resorption efficiency increases with increasing leaf nutrient status.

$\log _{10}$ transformation of Eq. (2) yields the linear form.

$\log _{10}\left(\mathrm{Nu}_{\mathrm{sen}}\right)=\alpha^{\prime}+\beta \times \log _{10}\left(\mathrm{Nu}_{\mathrm{gr}}\right)$ 


\subsection{Statistical Analysis}

The Kolmogorov-Smirnov test and Levene's test were conducted to test the homogeneity and normality of the variance of our data before statistical analysis. One-way ANOVA with Tukey's honestly significant difference (Tukey's HSD) was used to identify significant $(P<0.05)$ differences in chemical concentrations and resorption efficiency among the 11 tree species. In addition, we used major axis regression to fit the nutrient concentrations of senescent and green leaves to estimate the $\beta$ coefficient and test the significance of the correlation between the $\beta$ coefficient and $1(P<0.05)$. The above statistical analyses were carried out using SPSS 23.0 (SPSS Inc., Chicago, Illinois, USA), and figures were drawn in Origin 2018 (OriginLab, Northampton, MA, USA).

\section{Results}

\subsection{Concentrations of $\mathrm{K}, \mathrm{Ca}, \mathrm{Na}$ and $\mathrm{Mg}$ in the Green and Senescent Leaves}

The concentrations of $\mathrm{K}, \mathrm{Ca}, \mathrm{Na}$ and $\mathrm{Mg}$ in both green and senescent leaves showed significant differences among tree species, but the changes of cation concentration among the species were similar in green and senescent leaves (Fig. 1). S. mukorossi showed higher $\mathrm{K}, \mathrm{Na}$ and $\mathrm{Mg}$ concentrations in both green and senescent leaves, while $C$. lanceolata and $L$. chinense presented higher Ca concentrations. In contrast, $C$. lanceolata exhibited lower $\mathrm{K}$ and $\mathrm{Na}$ concentrations, and $P$. massoniana presented lower $\mathrm{Ca}$ and $\mathrm{Mg}$ concentrations in green and senescent leaves. Regardless of the tree species, the concentrations of $\mathrm{K}, \mathrm{Na}$ and $\mathrm{Mg}$ were higher in green leaves than those in senescent ones, while in evergreen broad-leaved trees and coniferous trees, the $\mathrm{Ca}$ concentration was lower in green leaves than in senescent leaves.

\subsection{Resorption Efficiency and Resorption Proficiency of $\mathrm{K}, \mathrm{Ca}, \mathrm{Na}$ and $\mathrm{Mg}$}

$\mathrm{K}$ and $\mathrm{Na}$ showed significant resorption regardless of the tree species, and significant $\mathrm{Mg}$ resorption was also detected in all tree species except for $S$. superba and $S$. mukorossi, while Ca displayed accumulation in most of the investigated tree species. Fig. 2. Among the examined elements, more than $70 \%$ of $\mathrm{K}$ was resorbed in C. lanceolata, P. massoniana, L. communis, C. camphora and S. superba, which was significantly higher than the resorption efficiencies in E. decipiens, L. formosana and L. chinense $(<50 \%)$. In contrast, the highest resorption efficiency of $\mathrm{Na}$ was detected in P. massoniana (50.2\%), while the efficiency was lower than $20 \%$ in L. formosana, S. mukorossi and L. chinense. Higher Mg resorption efficiencies $(>50 \%)$ were observed in L. chinense, C. lanceolata and P. massoniana than in the other trees. Although deciduous broad-leaved trees showed Ca resorption, both evergreen broad-leaved trees and coniferous trees showed significant $\mathrm{Ca}$ accumulation (except for E. decipiens). Additionally, the highest resorption proficiency for $\mathrm{K}$ was found in $C$. lanceolata and the lowest in L. chinensis, while the highest resorption proficiency for $\mathrm{Mg}$ was detected in L. chinensis and the lowest in S. mukorossi. However, the resorption proficiency for Na displayed few significant differences among the tree species.

\subsection{Correlations between Leaf Nutrient Status and Resorption Efficiency}

The concentrations of $\mathrm{K}, \mathrm{Ca}$ and $\mathrm{Mg}$ in senescent leaves were significantly positively correlated with those in green leaves, but the concentrations of $\mathrm{Na}$ showed little similarity between senescent leaves and green leaves. The $\beta$ values for $\mathrm{K}$ and $\mathrm{Mg}$ were greater than 1 , indicating that the resorption efficiencies of $\mathrm{K}$ and $\mathrm{Mg}$ decreased with increasing concentrations of $\mathrm{K}$ and $\mathrm{Mg}$ in green leaves (Fig. 3). Nevertheless, the $\beta$ values for $\mathrm{Ca}$ were less than 1 , indicating that the resorption efficiency of $\mathrm{Ca}$ increased with increasing concentrations of $\mathrm{Ca}$ in green leaves. In other words, the accumulation of $\mathrm{Ca}$ decreased with an increasing $\mathrm{Ca}$ concentration in green leaves. In addition, the concentrations of $\mathrm{K}$ and $\mathrm{Ca}$ in green leaves were significantly positively correlated with specific leaf area, indicating that the greater the specific leaf areas, the higher the concentrations of $\mathrm{K}$ and $\mathrm{Ca}$ in green leaves (Fig. 4). 

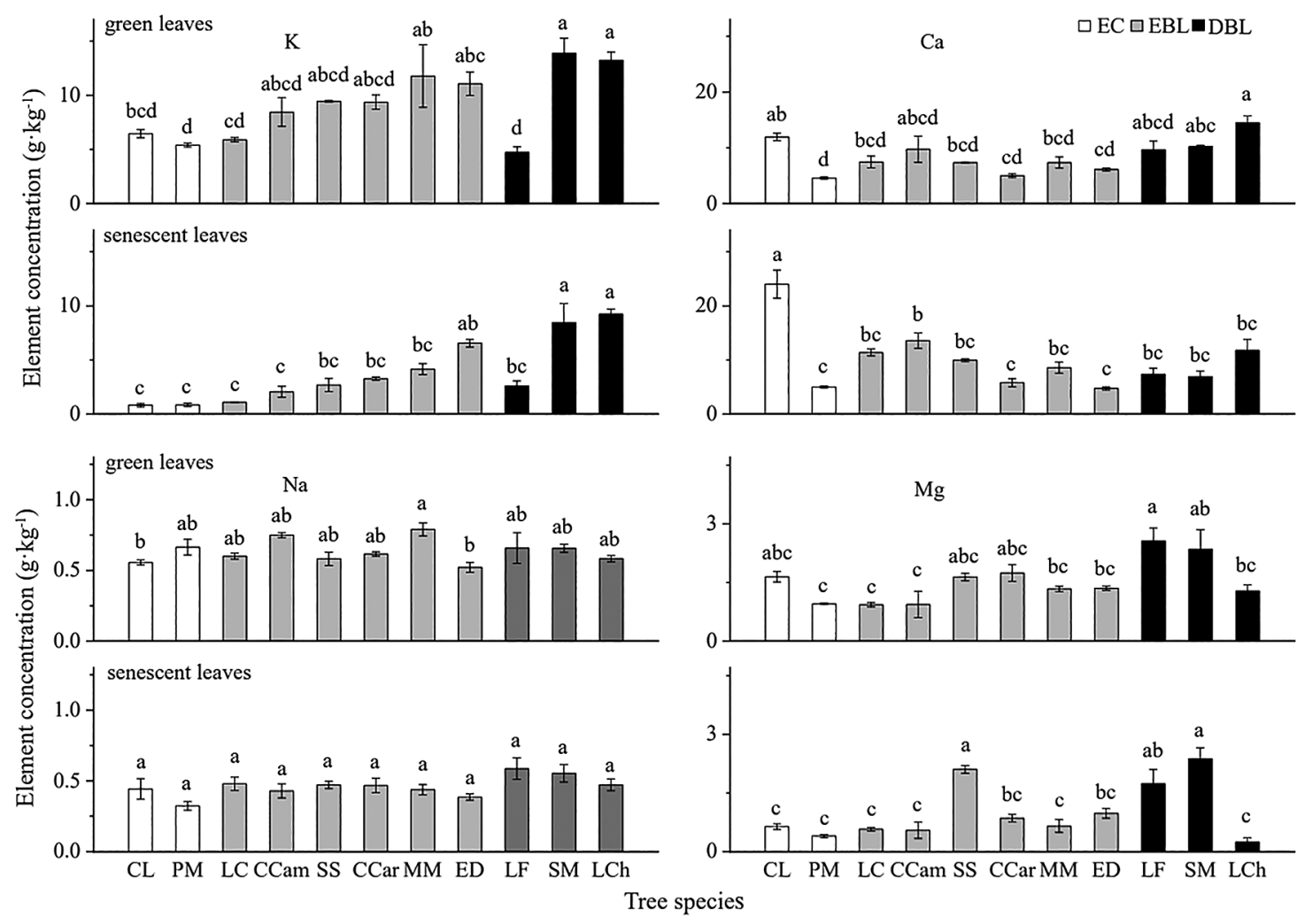

Figure 1: The concentrations of four cation elements in green and senescent leaves in studied tree species (mean $\pm \mathrm{SE}, \mathrm{n}=3$ ). Different lowercase letters indicate that the element concentrations of green leaves and senescent leaves show significant differences among different tree species $(P<0.05)$. EC: Evergreen coniferous species, EBL: Evergreen broad-leaved species; DBL: Deciduous broad-leaved species. CL: Cunninghamia lanceolata, PM: Pinus massoniana, LC: Lindera communis, CCam: Cinnamomum camphora, SS: Schima superba, CCar: Castanopsis carlesii, MM: Michelia macclurei, ED: Elaeocarpus decipiens, LF: Liquidambar formosana, SM: Sapindus mukorossi, LCh: Liriodendron chinense. The same abbreviations are used below

\section{Discussion}

Nutrient resorption is one of the most important mechanisms for modulating the balance of nutrients in plant tissues, although the resorption patterns of multiple nutrients among functional types are not fully understood [3,6]. In humid and rainy subtropical areas, the resorption of cation nutrients is particularly critical due to highly cation nutrient leaching loss from soil [33]. Our results partly supported the hypothesis that trees in the subtropical areas would display efficient $\mathrm{K}, \mathrm{Ca}, \mathrm{Na}$, and $\mathrm{Mg}$ resorption but that the resorption efficiency could be regulated by the nutrient status and specific leaf areas of green leaves among the different tree functional types. It was shown that $\mathrm{K}, \mathrm{Na}$ and $\mathrm{Mg}$ were mainly resorbed by trees in the common garden, while $\mathrm{Ca}$ accumulated in the senescent leaves of most trees. These results are similar to the findings of Liu et al. [11]. Furthermore, the resorption efficiencies of $\mathrm{K}$ and $\mathrm{Mg}$ and the accumulation of $\mathrm{Ca}$ decreased with increasing nutrient concentrations in green leaves. Overall, the nutrient resorption of $\mathrm{K}, \mathrm{Na}$ and $\mathrm{Mg}$ was higher in evergreen coniferous trees and evergreen broad-leaved trees than in deciduous broad-leaved trees, while Ca mainly accumulated in evergreen coniferous trees and evergreen broad-leaved trees. These findings indicate that the resorption of cation nutrients may depend on the elements and functional types involved. 


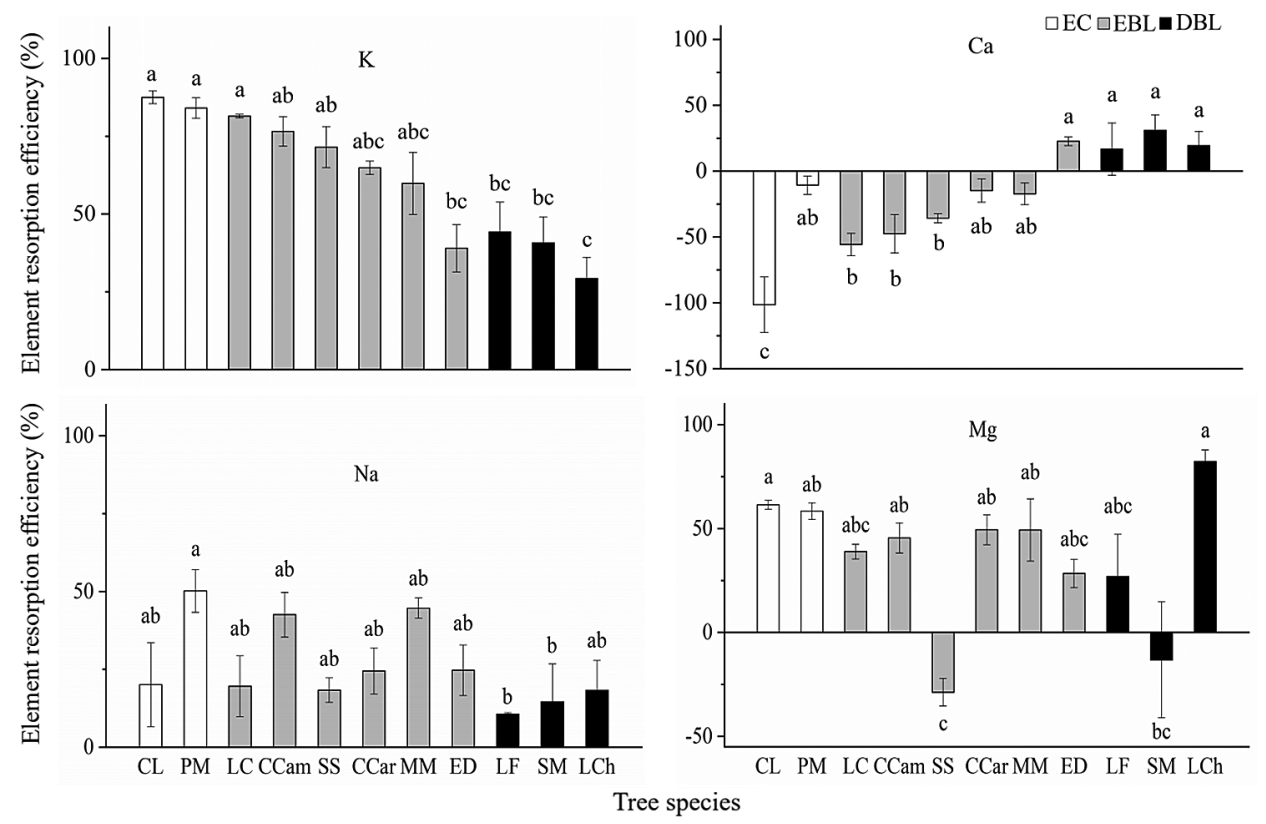

Figure 2: The resorption efficiencies of four cation elements in studied tree species (mean $\pm \mathrm{SE}, \mathrm{n}=3$ ). Different lowercase letters indicate that the element resorption efficiencies show significant diffierences among different tree species $(P<0.05)$
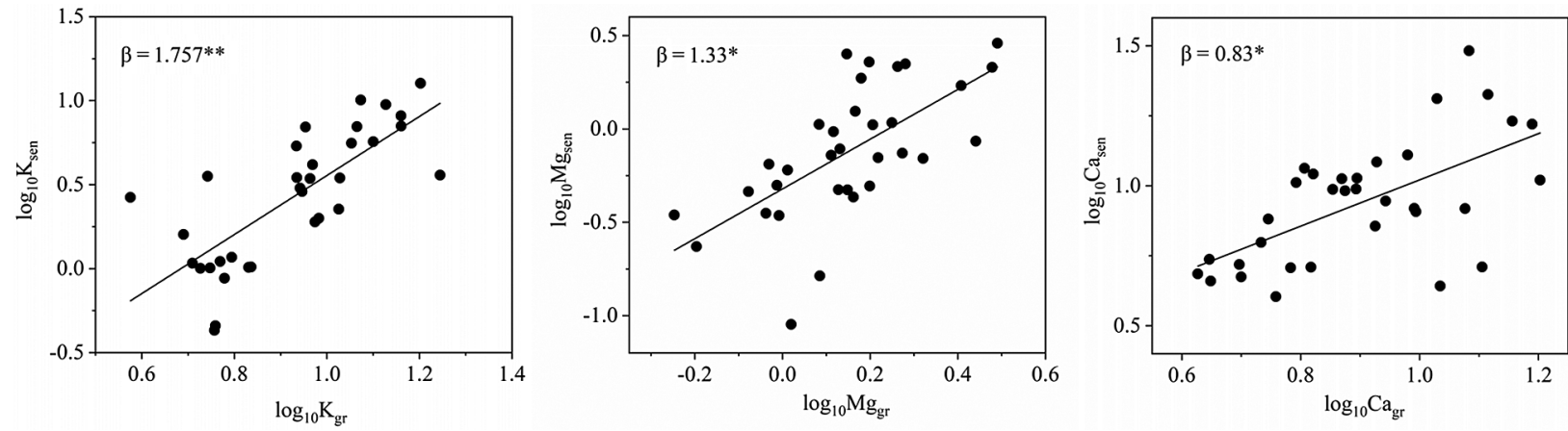

Figure 3: Major axis regression (Eq. (3)) for $\log 10$-transformed nutrient concentrations in senesced $v s$. green leaves (corrected for mass loss). $\beta>1$ indicates a decreased resorption efficiency with an increased leaf nutrient status; $\beta<1$ indicates an increased resorption efficiency with an increased leaf nutrient status. ${ }^{*} \beta$ indicates that the value differs significantly from 1

Plant nutrient concentrations can reflect the overall status of ecosystem nutrients and the nutrient use strategies of plants $[14,17]$. The nutrient values recorded in the green leaves of subtropical tree species studied are consistent with the results of previous studies in this area [34]. However, compared with the average values reported for plants in China by Han et al. [35], the concentrations of $\mathrm{K}, \mathrm{Ca}, \mathrm{Na}$ and $\mathrm{Mg}$ in the green leaves of our common garden plants were lower. This disparity may be due to the superior hydrothermal conditions in the subtropical region, heavy leaching, and strong biological cycles [33]. Generally, deciduous plants show higher nutrient concentrations than evergreen plants [6,35]. According to our research results, the nutrient concentrations of the green leaves of the deciduous trees were higher than those of evergreen trees to some extent. However, we found that not all of the nutrients examined in 
the subtropical plants follow this general pattern. For example, the Na concentration in green leaves showed no significant difference between deciduous trees and evergreen trees (Fig. 1). Our results indicate that the differences shown in previous studies do exist but that they are not universal, especially for trace elements for which plants exhibit a lower demand, such as $\mathrm{Na}$.
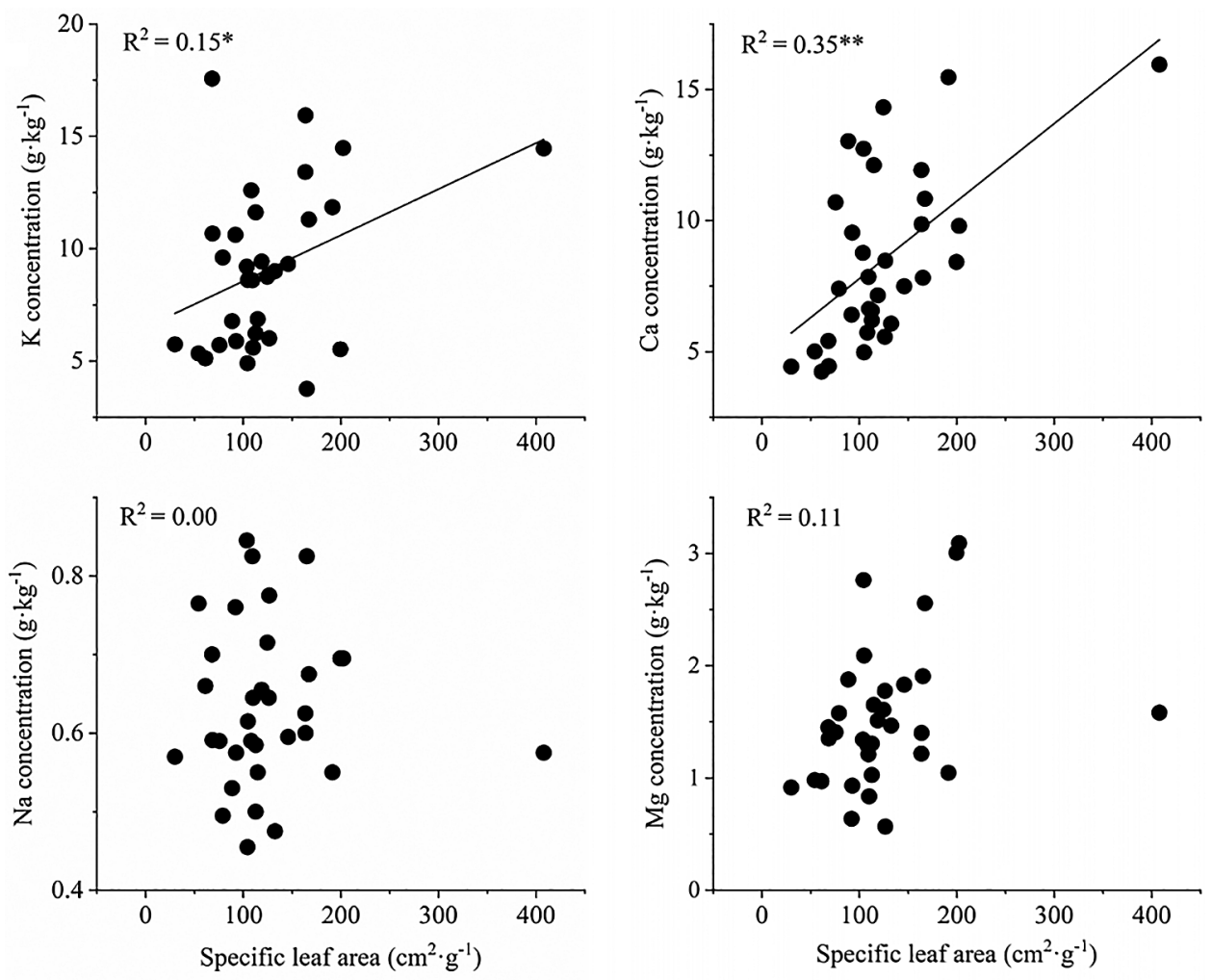

Figure 4: Linear correlation analysis between specific leaf area and element concentration of green leaves. $* P<0.05 ; * * P<0.01$

Our results partly support the hypothesis that the resorption of $\mathrm{K}, \mathrm{Ca}, \mathrm{Na}$ and $\mathrm{Mg}$ differs significantly among functional types. We found that evergreen coniferous trees exhibited the highest resorption efficiency for $\mathrm{K}$ and $\mathrm{Na}$, followed by evergreen broad-leaved trees, while deciduous trees presented the lowest resorption efficiency for $\mathrm{K}$ and $\mathrm{Na}$ (Fig. 2). It is well-known that both $\mathrm{K}$ and $\mathrm{Na}$ are leachable elements. The leaves of conifers with rough surfaces may be more easily leached by precipitation [36]. In this study, the leaf surfaces of $C$. lanceolata and P. massoniana were rougher than those of broad-leaved trees, which may lead to the greater leaching of $\mathrm{K}$ and $\mathrm{Na}$ in the leaves, and showing higher $\mathrm{K}$ and $\mathrm{Na}$ resorption. $\mathrm{Mg}$ is also easily transferred by plants [37]. Qiu et al. reported that the resorption efficiency of $\mathrm{Mg}$ is based on the actual demand in the plant. Plants may display a higher nutrient resorption efficiency in the condition of lacking $\mathrm{Mg}$ [37]. In this study, $\mathrm{Mg}$ accumulated in S. superba and S. mukorossi, while the other tree species showed higher $\mathrm{Mg}$ resorption efficiency (>25\%), indicating that $S$. superba and $S$. mukorossi could be less limited by Mg compared with other species.

Differences in $\mathrm{Ca}$ accumulation could also be observed among functional types (Fig. 2). Ca resorption was observed in the deciduous broad-leaved trees, while Ca showed obvious accumulation in the senescent leaves of evergreen coniferous and evergreen broad-leaved trees. The largest accumulation of $\mathrm{Ca}$ in the senescent leaves was observed in C. lanceolata, which was similar to the results of previous studies 
$[38,39]$. The dead leaves fall from the trunk only after they decompose on the tree for many years. During this period, large amounts of Ca could accumulate in senescent leaves [38]. To more objectively and definitively estimate the degree to which the trees reused nutrients, we also evaluated the resorption proficiency. The results showed that the differences in the resorption proficiency among the different functional types were similar to those observed for the resorption efficiency. Overall, the resorption proficiencies of $\mathrm{K}, \mathrm{Na}$ and $\mathrm{Mg}$ in the evergreen coniferous and evergreen broad-leaved trees were relatively higher than those in the deciduous broad-leaved trees. These results confirmed that compared with deciduous trees, evergreen coniferous and evergreen broad-leaved trees achieved a higher nutrient resorption efficiency and proficiency by reducing the concentrations of cations in senescent leaves. This might be one of the most crucial advantages of evergreen coniferous and evergreen broad-leaved trees growing in poor subtropical soil, which is consistent with some recent studies [29,40].

Plant nutrients and plant traits are important factors controlling nutrient resorption. From the perspective of leaf economics, nutrient resorption reflects the relative cost of energy consumption in plants between taking up nutrients from the soil and resorbing nutrients from senescent leaves [28,41]. Resorption is more efficient in the presence of low nutrient concentrations if taking up nutrients from soil with poor nutrient conditions is more expensive for plants than resorbing them from senescent leaves [15,31]. In subtropical regions, the hot and humid climate and excessive human exploitation could contribute to large amounts of cations loss from the soil, resulting in low nutrient availability. However, the relationship between resorption efficiency and plant nutrient status differed among elements because of the different physiological and biochemical characteristics of these cations. Compared with other elements, $\mathrm{K}$ and $\mathrm{Mg}$ are more highly mobile in plants, so they can be easily resorbed from senescent leaves. Therefore, $\mathrm{K}$ and $\mathrm{Mg}$ resorption increased with decreasing concentrations in green leaves $(\beta>1)$, which was consistent with the results of Vergutz et al. [3]. In contrast, $\mathrm{Ca}$ is a structural element with poor mobility in the phloem, resulting that the resorption could be more expensive [12]. For this reason, the present study showed that the resorption efficiency of $\mathrm{Ca}$ increased with increasing $\mathrm{Ca}$ concentrations in green leaves $(\beta<1)$. In addition, the $\mathrm{K}$ and $\mathrm{Ca}$ concentrations of green leaves were significantly positively correlated with the specific leaf areas, which further revealed that trees with larger specific leaf areas have higher $\mathrm{K}$ and $\mathrm{Ca}$ concentrations in green leaves, resulting in lower $\mathrm{K}$ resorption efficiency and lower $\mathrm{Ca}$ accumulation.

\section{Conclusions}

$\mathrm{K}, \mathrm{Na}$ and $\mathrm{Mg}$ could be well resorbed by most of the investigated tree species in the subtropical area, but $\mathrm{Ca}$ showed accumulation during leaf senescence. Compared with deciduous broad-leaved trees, the resorption of $\mathrm{K}, \mathrm{Na}$ and $\mathrm{Mg}$ was generally substantially higher in evergreen coniferous and evergreen broad-leaved trees. Thus, evergreen coniferous trees and evergreen broad-leaved trees are more suitable for growth in subtropical areas where cations might be limited in soil. Therefore, it is suggested that evergreen coniferous trees such as $C$. lanceolata and evergreen broad-leaved trees such as $C$. camphora could be suitable for developing mixed coniferous and broad-leaved forests with relatively higher nutrient use strategies in the management of subtropical plantations.

Funding Statement: The study was supported by grants from National Natural Science Foundation of China (Grants 31800521, 31800373 and 31922052). Datasets for this research are included in this paper.

Conflicts of Interest: The authors declare that they have no conflicts of interest to report regarding the present study.

\section{References}

1. Watanabe, T., Broadley, M. R., Jansen, S., White, P. J., Takada, J. et al. (2007). Evolutionary control of leaf element composition in plants. New Phytologist, 174(3), 516-523. DOI 10.1111/j.1469-8137.2007.02078.x. 
2. Yue, K., Yang, W. Q., Peng, Y., Zhang, C., Huang, C. P. et al. (2016). Dynamics of multiple metallic elements during foliar litter decomposition in an alpine forest river. Annals of Forest Science, 73(2), 547-557. DOI 10.1007/s13595-016-0549-2.

3. Vergutz, L., Manzoni, S., Porporato, A., Novais, R. F., Jackson, R. B. (2012). Global resorption efficiencies and concentrations of carbon and nutrients in leaves of terrestrial plants. Ecological Monographs, 82(2), 205-220. DOI 10.1890/11-0416.1.

4. Zhang, H., Wang, J. N., Wang, J. Y., Guo, Z. W., Wang, G. G. et al. (2018). Tree stoichiometry and nutrient resorption along a chronosequence of metasequoia glyptostroboides forests in coastal China. Forest Ecology and Management, 430, 445-450. DOI 10.1016/j.foreco.2018.08.037.

5. Zong, N., Song, M., Zhao, G., Shi, P. (2020). Nitrogen economy of alpine plants on the north Tibetan plateau: Nitrogen conservation by resorption rather than open sources through biological symbiotic fixation. Ecology and Evolution, 10(4), 2051-2061. DOI 10.1002/ece3.6038.

6. Aerts, R. (1996). Nutrient resorption from senescing leaves of perennials: Are there general patterns? Journal of Ecology, 84(4), 597-608. DOI 10.2307/2261481.

7. Aerts, R., Chapin, F. S. (2000). The mineral nutrition of wild plants revisited: A re-evaluation of processes and patterns. Advances in Ecological Research, 30, 1-67. DOI 10.1016/S0065-2504(08)60016-1.

8. Killingbeck, K. T. (1996). Nutrients in senesced leaves: Keys to the search for potential resorption and resorption proficiency. Ecology, 77, 1716-1727. DOI 10.2307/2265777.

9. Wright, I. J., Reich, P. B., Cornelissen, J. H. C., Falster, D. S., Garnier, E. et al. (2010). Assessing the generality of global leaf trait relationships. New Phytologist, 166(2), 485-496. DOI 10.1111/j.1469-8137.2005.01349.x.

10. Du, B. M., Ji, H. W., Peng, C., Liu, X. J., Liu, C. J. (2017). Altitudinal patterns of leaf stoichiometry and nutrient resorption in quercus variabilis in the baotianman mountains, China. Plant \& Soil, 413 (1-2), 193-202. DOI 10.1007/s11104-016-3093-9.

11. Liu, C. C., Liu, Y. G., Guo, K., Wang, S. J., Yang, Y. (2014). Concentrations and resorption patterns of 13 nutrients in different plant functional types in the karst region of South-Western China. Annals of Botany, 113(5), 873-885. DOI 10.1093/aob/mcu005.

12. Zhang, M. X., Luo, Y., Yan, Z. B., Chen, J., Eziz, A. et al. (2018). Resorptions of 10 mineral elements in leaves of desert shrubs and their contrasting responses to aridity. Journal of Plant Ecology, 12(2), 358-366. DOI 10.1093/ jpe/rty034.

13. Oikawa, S., Matsui, Y., Oguro, M., Okanishi, M., Tanabe, R. et al. (2020). Species-specific nitrogen resorption proficiency in legumes and nonlegumes. Journal of Plant Research, 133(5), 639-648. DOI 10.1007/s10265020-01211-1.

14. Diehl, P., Mazzarino, M. J., Funesm, F., Fontenla, S., Gobbi, M. et al. (2003). Nutrient conservation strategies in native Andean-Patagonian forests. Journal of Vegetation Science, 14(1), 63-70. DOI 10.1111/j.1654-1103.2003. tb02128.x.

15. Kazakou, E., Garnier, E., Navas, M. L., Roumet, C., Collin, C. et al. (2007). Components of nutrient residence time and the leaf economics spectrum in species from Mediterranean old-fields differing in successional status. Functional Ecology, 21(2), 235-245. DOI 10.1111/j.1365-2435.2006.01242.x.

16. Qiu, X. C., Wang, H. B., Peng, D. L., Liu, X., Yang, F. et al. (2020). Thinning drives C:N:P stoichiometry and nutrient resorption in Larix principis-rupprechtii plantations in north China. Forest Ecology and Management, 462, 117984. DOI 10.1016/j.foreco.2020.117984.

17. Wu, H. L., Xiang, W. H., Ouyang, S., Xiao, W. F., Li, S. G. et al. (2020). Tree growth rate and soil nutrient status determine the shift in nutrient-use strategy of Chinese fir plantations along a chronosequence. Forest Ecology and Management, 460, 117896. DOI 10.1016/j.foreco.2020.117896.

18. Aerts, R., Cornelissen, J. H. C., van Logtestijn, R. S. P., Callaghan, T. V. (2007). Climate change has only a minor impact on nutrient resorption parameters in a high-latitude peatland. Oecologia, 151(1), 132-139. DOI 10.1007/ s00442-006-0575-0. 
19. Wang, Z., Jimoh, S. O., Li, X. L., Ji, B. M., Struik, P. C. et al. (2020). Different responses of plant N and P resorption to overgrazing in three dominant species in a typical steppe of inner Mongolia, China. PeerJ, 8, e9915. DOI 10.7717/peerj.9915.

20. Shi, B., Ling, X., Cui, H., Song, W., Gao, Y. et al. (2020). Response of nutrient resorption of Leymus chinensis to nitrogen and phosphorus addition in a meadow steppe of northeast China. Plant Biology, 22(6), 1123-1132. DOI 10.1111/plb.13153.

21. Yang, Y. S., Wang, L. X., Yang, Z. J., Xu, C., Xie, J. S. et al. (2018). Large ecosystem service benefits of assisted natural regeneration. Journal of Geophysical Research: Biogeosciences, 123(2), 676-687. DOI 10.1002/ $2017 J G 004267$.

22. Zhou, L. L., Li, S. B., Jia, Y. Y., Heal, K. V., He, Z. M. et al. (2020). Spatiotemporal distribution of canopy litter and nutrient resorption in a chronosequence of different development stages of Cunninghamia lanceolata in southeast China. Science of the Total Environment, 762, 143153. DOI 10.13287/j.1001-9332.201907.007.

23. Vitousek, P. M., Sanford, R. L. (1986). Nutrient cycling in moist tropical forest. Annual Review of Ecology and Systematics, 17(1), 137-167. DOI 10.1146/annurev.es.17.110186.001033.

24. Zeng, Y. L., Fang, X., Xiang, W. H., Deng, X. W., Peng, C. H. (2017). Stoichiometric and nutrient resorption characteristics of dominant tree species in subtropical Chinese forests. Ecology and Evolution, 7(24), 1103311043. DOI 10.1002/ece3.3527.

25. He, M. S., Yan, Z. B., Cui, X. Q., Gong, Y. M., Li, K. H. et al. (2020). Scaling the leaf nutrient resorption efficiency: Nitrogen vs phosphorus in global plants. Science of the Total Environment, 729, 138920. DOI 10.1016/j.scitotenv.2020.138920.

26. Zhao, W. Q., Kou, Y. P., Wang, X. H., Wu, Y. H., Bing, H. J. et al. (2020). Broad-scale distribution of diazotrophic communities is driven more by aridity index and temperature than by soil properties across various forests. Global Ecology and Biogeography, 29(12), 2119-2130. DOI 10.1111/geb.13178.

27. Zheng, X. Z., Zhang, X. X., Lin, W. S., Liu, X. F., Chu, H. Y. et al. (2018). Ects of different tree species on soil dissolved organic carbon and microbial biomass carbon in subtropical China. Journal of Fujian Normal University (Natural Science Edition), 34(6), 86-93. DOI 10.12046/j.issn.1000-5277.2018.06.14.

28. Wright, M., Westoby, I. J. (2003). The leaf size-twig size spectrum and its relationship to other important spectra of variation among species. Oecologia, 135(4), 621-628. DOI 10.1007/s00442-003-1231-6.

29. Liu, H. W., Liu, W. D., Wang, W., Chai, J., Tao, J. P. (2015). Leaf traits and nutrient resorption of major woody species in the karst limestone area of Chongqing. Acta Ecologica Sinica, 35(12), 4071-4080. DOI 10.5846/ stxb201310262584.

30. Wang, X. C., Chen, Y., Liu, F., Zhao, R., Quan, X. K. et al. (2020). Nutrient resorption estimation compromised by leaf mass loss and area shrinkage: Variations and solutions. Forest Ecology and Management, 472, 118232. DOI 10.1016/j.foreco.2020.118232.

31. Van Heerwaarden, L. M., Toet, S., Aerts, R. (2003). Current measures of nutrient resorption efficiency lead to a substantial underestimation of real resorption efficiency: Facts and solutions. Oikos, 101(3), 664-669. DOI 10.1034/j.1600-0706.2003.12351.x.

32. Kobe, R. K., Lepczyk, C. A., Iyer, M. (2005). Resorption efficiency decreases with increasing green leaf nutrients in a global data set. Ecology, 86, 2780-2792. DOI 10.1890/04-1830.

33. Chapin, F. S., Matson, P. A., Vitousek, P. M. (2011). Principles of terrestrial ecosystem ecology. Springer, USA.

34. Lin, C. C. (1999). Calorific values and nutrient composition of the leaves of monsoon evergreen broadleaved forest and some forest-edge plants on gushan mountain in Fuzhou. Acta Ecologica Sinica, 19(6), 832-836.

35. Han, W. X., Fang, J. Y., Reich, P. B., Woodward, F. I., Wang, Z. H. (2011). Biogeography and variability of eleven mineral elements in plant leaves across gradients of climate, soil and plant functional type in China. Ecology Letters, 14(8), 788-796. DOI 10.1111/j.1461-0248.2011.01641.x.

36. Huang, J., Wang, X., Yan, E. (2007). Leaf nutrient concentration, nutrient resorption and litter decomposition in an evergreen broad-leaved forest in eastern China. Forest Ecology and Management, 239(1), 150-158. DOI 10.1016/ j.foreco.2006.11.019.

37. Qiu, B. J., He, X. H. (1985). Nutrition of plants. Science Press, China. 
38. Lin, B. P., He, Z. M., Lin, S. S., Hu, H. T., Qiu, L. J. et al. (2017). Needles macronutrient concentrations and retranslocation characteristics in Chinese fir plantations of different ages. Journal of Forest and Environment, 37(1), 34-39. DOI 10.13324/j.cnki.jfcf.2017.01.006.

39. Meng, Q. Q., Ge, L. L., Wang, J., Yang, X. M., Lin, Y. et al. (2019). Seasonal dynamics on nutrient concentrations and resorptions in the leaves of Castanopsis kawakamii and Cunninghamia lanceolata, Sanming, China. Journal of Sichuan Agricultural University, 37(3), 366-373. DOI 10.16036/j.issn.1000-2650.2019.03.013.

40. Zhou, L. L., Qian, R. L., Li, S. B., Dong, B. W., Chen, B. Y. et al. (2019). Leaf functional traits and nutrient resorption among major silviculture tree species in coastal sandy site. Chinese Journal of Applied Ecolog, 30(7), 2320-2328. DOI 10.13287/j.1001-9332.201907.007.

41. Jiang, C. M., Yu, G. R., Li, Y. N., Cao, G. M., Yang, Z. P. et al. (2012). Nutrient resorption of coexistence species in alpine meadow of the Qinghai-Tibetan plateau explains plant adaptation to nutrient-poor environment. Ecological Engineering, 44, 1-9. DOI 10.1016/j.ecoleng.2012.04.006. 